\title{
Medical physics aspects of cancer care in the Asia Pacific region: 2011 survey results
}

\author{
Kron $\mathrm{T}^{1}$, Azhari $\mathrm{HA}^{2}$, Voon $\mathrm{EO}^{3}$, Cheung $\mathrm{KY}^{4}$, Ravindran $\mathrm{P}^{5}$, Soejoko $\mathrm{D}^{6}$, \\ Inamura $\mathrm{K}^{7}$, Han $\mathrm{Y}^{8}$, Ung $\mathrm{NM}^{9}$, Bold $\mathrm{L}^{10}$, Win $\mathrm{UM}^{11}$, Srivastava $\mathrm{R}^{12}$, Meyer $\mathrm{J}^{13}$, \\ Farrukh $\mathrm{S}^{14}$, Rodriguez L ${ }^{15}$, Kuo $\mathrm{M}^{16}$, Lee $\mathrm{JCL}^{17}$, Kumara $\mathrm{A}^{18}$, Lee $\mathrm{CC}^{19}$, \\ Krisanachinda $\mathrm{A}^{20}$, Nguyen $\mathrm{XC}^{21}, \mathrm{Ng} \mathrm{KH}^{22}$
}

1 Physical Sciences, Peter MacCallum Cancer Centre, and RMIT University, Melbourne, Australia

2 Department of Medical Physics and Biomedical Engineering, Gono Bishwabidyalay (University), Savar, Dhaka, Bangladesh

3 Radiation Safety and Quality Unit, Department of Scientific Services, Ministry of Health, Brunei Darussalam

4 Department of Clinical Oncology, Prince of Wales Hospital, Hong Kong, China SAR

5 Department of Radiation Oncology, Christian Medical College, Vellore, India

6 Physics Department, University of Indonesia, Jakarta, Indonesia

7 Professor Emeritus, Osaka University, Onoharahigashi 6-35-7, Minoh-city, Japan

8 Sungkyunkwan University, Samsung Medical Centre, Republic of Korea

9 Clinical Oncology Unit, University of Malaya, Kuala Lumpur, Malaysia

10 Radiotherapy Department, National Cancer Centre, Ulaanbaatar, Mongolia

11 Ministry of Health, Yangoon, Myanmar

12 B.P. Koirala Memorial Cancer Hospital, Bharatpur, Chitwan, Nepal

13 Department of Physics and Astronomy, University of Canterbury, Christchurch, New Zealand

14 Department of Radiation Oncology, Atomic Energy Medical Centre, Karachi, Pakistan

15 Department of Radiotherapy, Jose R. Reyes Memorial Medical Center, Manila, Philippines

16 Department of Radiation Oncology, Cancer Institute (Hospital), Chinese Academy of Medical Sciences

17 Department of Therapeutic Radiology, National Cancer Centre, Singapore

18 Division of Medical Physics, National Cancer Institute, Sri Lanka

19 Department of Medical Imaging and Radiological Sciences, Chang Gung University, Taiwan

20 Department of Radiology, Faculty of Medicine, Chulalongkorn University, Bangkok, Thailand

21 K Hospital, National Cancer Institute, Hanoi, Vietnam

22 Department of Biomedical Imaging, University of Malaya, and Medical Physics Unit, University of Malaya Medical Centre, Kuala Lumpur, Malaysia

Received 2 December 2011; accepted 22 January 2012

\section{ABSTRACT}

Background: Medical physicists are essential members of the radiation oncology team. Given the increasing complexity of radiotherapy delivery, it is important to ensure adequate training and staffing. The aim of the present study was to update a similar survey from 2008 and assess the situation of medical physicists in the large and diverse Asia Pacific region.

\footnotetext{
Presented in parts at the $32^{\text {nd }}$ Annual Meeting of the Association of Medical Physicists of India (AMPI), November 2011, Vellore, India

* Corresponding author. Address: Peter MacCallum Cancer Institute, Locked Bag 1, A'Beckett St., Melbourne 8006, Australia. E-mail: tomas.kron@petermac.org (Tomas Kron)
} 
Methods: Between March and July 2011, a survey on profession and practice of radiation oncology medical physicists (ROMPs) in the Asia Pacific region was performed. The survey was sent to senior physicists in 22 countries. Replies were received from countries that collectively represent more than half of the world's population. The survey questions explored five areas: education, staffing, work patterns including research and teaching, resources available, and job satisfaction.

Results and discussion: Compared to a data from a similar survey conducted three years ago, the number of medical physicists in participating countries increased by $29 \%$ on average. This increase is similar to the increase in the number of linear accelerators, showing that previously identified staff shortages have yet to be substantially addressed. This is also highlighted by the fact that most ROMPs are expected to work overtime often and without adequate compensation. While job satisfaction has stayed similar compared to the previous survey, expectations for education and training have increased somewhat. This is in line with a trend towards certification of ROMPs.

Conclusion: As organisations such as the International Labour Organization (ILO) start to recognise medical physics as a profession, it is evident that despite some encouraging signs there is still a lot of work required towards establishing an adequately trained and resourced medical physics workforce in the Asia Pacific region. (C) 2012 Biomedical Imaging and Intervention Journal. All rights reserved.

\section{INTRODUCTION}

The International Labour Organization (ILO) has recently classified 'medical physicist' as an occupation in the International Standard Classification of Occupations-08 (ICSO-08) under physicists and astronomers [1]. This is indicative of the increasing awareness of medical physics as a profession in its own right. While the actual number of medical physicists is relatively small compared to other professional groups in medicine, they perform a vast variety of different tasks. This applies also to its subspecialty of radiation oncology medical physics, in which the majority of medical physicists work.

In 2008, a survey was conducted to determine the characteristics of the medical physics workforce in countries within the region of the Asia-Oceania Federation of Organizations for Medical Physics (AFOMP) [2]. It probed workforce numbers and typical workloads, training and education, and job satisfaction among medical physicists working in radiation oncology in 16 countries in the Asia Pacific region. The aim of the present study was to update this information three years after the initial survey. In addition to this, questions on certification and research opportunities were added to enrich the data and reflect on recent trends in health professions.

As in 2008, the definition of the clinical medical physicist used was that of the AFOMP [3]. It is worth repeating here:

"A qualified Clinical Medical Physicist is a person who is qualified with a master university degree or equivalent in physical science or engineering science and working in alliance with medical staff in hospitals, universities or research institutes. In addition to his/her university degree or equivalent, a Clinical Medical Physicist shall have specialist training in the concepts and techniques of applying physics in medicine including training in the medical application of both ionizing and non-ionizing radiation. This person must have a thorough knowledge in one or more sub-fields of medical physics, including radiotherapy physics, imaging physics, nuclear medicine physics and radiation protection."

A key point in this definition is that a medical physicist has both a sound theoretical understanding of the science as well as clinical training in its application. As technology advances rapidly, an additional requirement is commonly the participation in Continued Professional Development (CPD) [4, 5]. This requires significant resources that may not be available everywhere. There is therefore an important role for professional organisations such as the AFOMP, which has the mission to advance and standardise medical physics practice in the region. In this context, AFOMP has initiated a periodic survey of medical physics practice in the region, the first of which was conducted in 2008. The present report summarises the outcomes of the second survey in 2011.

Specifically, it is the aim of the present article to:

- Document differences and commonalities in education and clinical experience required for radiation oncology medical physicists (ROMPs) in the Asia Pacific region,

- Update general information on the number of physicists and their relation to equipment and other professions,

- Document the tasks undertaken by physicists in radiation oncology, including research and teaching, and

- Explore resources, status and job satisfaction available to and among medical physicists.

Where possible, comparisons with the 2008 survey have been included to highlight any changes over the three-year period.

\section{METHODS}

Based on the 2008 survey [2], a questionnaire was designed to explore medical physics practice in radiation oncology. The 2008 survey relied on an ad-hoc group of medical physicists in 16 countries to provide information on the situation in these countries. As this approach was successful, a similar approach was used in 2011. 
Table 1 Education and training of radiation oncology medical physicists (ROMPs) in the Asia/Pacific region.

\begin{tabular}{|c|c|c|c|c|}
\hline & $\begin{array}{l}\text { What is the expected } \\
\text { academic degree for } \\
\text { ROMPs? }\end{array}$ & $\begin{array}{l}\text { Is there a formal } \\
\text { training program? }\end{array}$ & $\begin{array}{c}\text { Typical length of clinical } \\
\text { training (years) }\end{array}$ & $\begin{array}{l}\text { Is there professional } \\
\text { certification? }\end{array}$ \\
\hline Australia & $\mathrm{MSc}$ & yes & 3 & yes, by ACPSEM \\
\hline Bangladesh & MSc & under development & 2 (planned) & planned \\
\hline Brunei & MSc preferred & no & & no \\
\hline $\begin{array}{l}\text { Hong Kong } \\
\text { China }\end{array}$ & $\begin{array}{l}\text { MSc, } \mathrm{PhD} \text { required for } \\
\text { higher rank }\end{array}$ & yes, residency program & 2 & yes, since 2006 \\
\hline India & MSc & $\begin{array}{l}\text { yes, residency available } \\
\text { at selected hospitals }\end{array}$ & 1 & yes, by CMPI \\
\hline Indonesia & $\mathrm{MSc}$ & & 2 (planned) & \\
\hline Japan & $\mathrm{BSc}$ required & in development & 3 years clinical experience & $\begin{array}{l}\text { yes by Japanese Board of } \\
\text { Medical Physicists }\end{array}$ \\
\hline $\begin{array}{l}\text { Republic of } \\
\text { Korea }\end{array}$ & MSc & $\begin{array}{l}\text { yes, two programmes } \\
\text { accredited }\end{array}$ & $3(2$ if $\mathrm{PhD})$ & $\begin{array}{c}\text { yes includes a } 100 \mathrm{hrs} \text { lecture } \\
\text { course by KSMP }\end{array}$ \\
\hline Malaysia & BSc, MSc preferred & $\begin{array}{l}\text { not local but IAEA } \\
\text { ROMP training }\end{array}$ & 2 to 3 & no \\
\hline Mongolia & $\mathrm{BSc}$ required & in discussion & 3 months required & planned within 10 years \\
\hline Myanmar & MSc & no & & no but planned \\
\hline Nepal & MSc & no & & planned \\
\hline New Zealand & MSc & yes & 3 & yes, by ACPSEM \\
\hline Pakistan & MSc & $\begin{array}{c}\text { only MS in medical } \\
\text { physics }\end{array}$ & 1 & $\begin{array}{c}\text { planned, expected to } \\
\text { commence within next } 05 \\
\text { years }\end{array}$ \\
\hline $\begin{array}{l}\text { Papua New } \\
\text { Guinea }\end{array}$ & not applicable & no & & no \\
\hline Philippines & MSc preferred & $\begin{array}{l}\text { participation in IAEA } \\
\text { pilot }\end{array}$ & 2 to 3 & commenced in 2010 \\
\hline PR China & MSc preferred & no & 2 years clinical experience & yes exam \\
\hline Singapore & MSc preferred & $\begin{array}{l}\text { each hospital determines } \\
\text { its own }\end{array}$ & $2+$ overseas attachment & no - profession too small \\
\hline Sri Lanka & $\begin{array}{c}\text { MSc to be completed } \\
\text { within } 5 \text { years after } \\
\text { selection }\end{array}$ & yes & & $\begin{array}{c}\text { planned within } 3 \text { years - lack of } \\
\text { supervisors }\end{array}$ \\
\hline $\begin{array}{l}\text { Republic of } \\
\text { China (Taiwan) }\end{array}$ & $\begin{array}{l}\text { BSc, MSc preferred - } \\
\text { now MSc de facto }\end{array}$ & $\begin{array}{l}3 \mathrm{MS} / \mathrm{PhD} \text { programs, no } \\
\text { residency program }\end{array}$ & $\begin{array}{l}\text { varies from } 2 \text { years for } \\
\text { PhDs to } 5 \text { years for BScs }\end{array}$ & $\begin{array}{c}\text { yes, exam and } 1 \text { year CSMPT } \\
\text { membership }\end{array}$ \\
\hline Thailand & MSc & $\begin{array}{l}\text { yes - grad dip of clinical } \\
\text { sciences program in } \\
\text { Med Phys ( } 2 \text { years) }\end{array}$ & 2 years & yes, exam + clinical training \\
\hline Vietnam & BSc, MSc preferred & $\begin{array}{l}\text { yes but syllabus may } \\
\text { depend on hospital }\end{array}$ & & planned within 2 years \\
\hline
\end{tabular}

The questionnaire was sent to 20 senior physicists in the region who have been active in the field for several years. Many of them have represented their medical physics organisations at AFOMP, the International Organization of Medical Physics (IOMP), and the International Atomic Energy Agency (IAEA) and were, as such, considered to be familiar with the state of medical physics in their respective countries. Including the initiators of the survey, the questionnaires reached 22 countries and territories in the Asia Pacific region.

The questionnaire was distributed in English and covered seven main areas in five themes with all 
Table 2a Number of ROMPs and irradiation equipment in the Asia/Pacific Region.

\begin{tabular}{|c|c|c|c|c|c|c|}
\hline & \multicolumn{2}{|c|}{$\begin{array}{l}\text { Number of } \\
\text { ROMPs }\end{array}$} & \multirow[t]{2}{*}{ Brachytherapy units } & \multirow{2}{*}{$\begin{array}{c}\text { Tele Cobalt } \\
\text { units } \\
\text { number }\end{array}$} & \multirow{2}{*}{$\begin{array}{c}\text { Linacs } \\
\text { number }\end{array}$} & \multirow[t]{2}{*}{ Other* } \\
\hline & 2008 & 2011 & & & & \\
\hline Australia & 224 & 274 & $\begin{array}{l}\text { about half the centres } \\
\text { HDR, more I125 seeds } \\
\text { in urology }\end{array}$ & 0 & 130 & IMRT, IGRT, HT 1, GK 1 \\
\hline Bangladesh & 9 & 23 & 5 (2 LDR, 3 HDR) & 11 & 8 & IMRT 2, IGRT 1 \\
\hline Brunei & & 2 & & & $\begin{array}{l}\text { in the } \\
\text { process of } \\
\text { tendering }\end{array}$ & \\
\hline Hong Kong China & 42 & 43 & full range & 0 & 32 & HT 3, CK 1, GK 1, IMRT, IGRT \\
\hline India & 550 & 800 & LDR 15, HDR 173 & 277 & 157 & HT 3, GK 8, CK 2, IMRT, IGRT \\
\hline Indonesia & 38 & 42 & 17 & 17 & 16 & IMRT, IGRT, SRS \\
\hline Japan & & 562 & LDR 1, HDR 124 & 11 & 816 & $\begin{array}{c}\text { HT 16, GK 46, CK 265, MT 15, } \\
\text { P 10, IMRT, IGRT }\end{array}$ \\
\hline Republic of Korea & 66 & 81 & & 0 & 119 & CK 8, PT 1, HT 14 \\
\hline Malaysia & 55 to 60 & 80 & several (4 from DIRAC) & 1 & 32 & CK 1, HT 2, IMRT, IGRT \\
\hline Mongolia & 3 & 6 & 1 & 2 & $\begin{array}{l}\text { linac will be } \\
\text { installed in } \\
2 \text { years }\end{array}$ & \\
\hline Myanmar & & 4 & 5 (from DIRAC) & 6 & 0 & \\
\hline Nepal & 10 & 10 & 2 & 4 & 3 & \\
\hline New Zealand & 44 & 55 & offered in few centres & 0 & 25 & IMRT, IGRT \\
\hline Pakistan & & 47 & 11 & 18 & 21 & IMRT, IGRT, SRS, CK1 GK1 \\
\hline Papua New Guinea & & 0 & manual in the past & 1 & 0 & \\
\hline Philippines & 30 & 40 & $\begin{array}{l}16 \text { centres with } \\
\text { brachytherapy }\end{array}$ & 8 & 26 & 10 IMRT, 3 IGRT,4SRS GK 1 \\
\hline PR China & 1181 & 1500 & many & 500 & 1200 & CK 1, IMRT, IGRT, SRS \\
\hline Singapore & 13 & 17 & $\begin{array}{l}\text { full range ( } 3 \text { from } \\
\text { DIRAC) }\end{array}$ & 0 & 18 & HT2, GK 1, IMRT, IGRT \\
\hline Sri Lanka & 8 & 9 & 3 (from DIRAC) & 10 & 2 & \\
\hline $\begin{array}{l}\text { Republic of China } \\
\text { (Taiwan) }\end{array}$ & 100 & 142 & 46 (all HDR) & 4 & 128 & $\begin{array}{c}\text { HT 10, CK 5, GK 8, P } 1 \text { (under } \\
\text { construction), IMRT, IGRT, } \\
\text { SRS }\end{array}$ \\
\hline Thailand & 76 & 81 & 24 (from DIRAC) & 23 & 45 & CK 1 , GK 1 \\
\hline Vietnam & 25 & 50 & 7 (from DIRAC) & 14 & 17 & CK 1 , GK 3 \\
\hline Total & 2410 & 3864 & & 907 & 2798 & \\
\hline
\end{tabular}

* IMRT $=$ Intensity Modulated Radiation Therapy, IGRT $=$ Image Guided Radiation Therapy, HT $=$ Helical Tomotherapy, CK $=$ Cyberknife, $\mathrm{GK}=$ Gammaknife, $\mathrm{PT}=$ proton and particle therapy, $\mathrm{MT}=$ microtron based radiotherapy, SRS = stereotactic radiosurgery

questions asked in 2008 included (some with minor clarifications). Some additional questions were included to probe important areas further.

1. Education, training and professional certification

In addition to questions on expected training, education and $\mathrm{CPD}$, the questionnaire probed the availability of a certification scheme.

2. Staffing numbers and treatment equipment

This section also included an assessment of the ratio of ROMPs to other professions and the overall population in participating countries. Most updated information on population numbers was taken from Wikipedia (en.wikipedia.org). It reflects data from 2010 or 2011 in all cases. Information on equipment provided in the questionnaires was supplemented with data from the Directory of Radiotherapy Centres (DIRAC) database maintained by the International Atomic Energy Agency (IAEA) (http://nucleus.iaea.org/HHW/DBStatistics/DIRAC/inde x.html).

3. Workload

This part of the questionnaire was enlarged compared to 2008 to provide more details on the typical activities of ROMPs in the region. For example, information technology (IT) was explicitly included and 
Table 2b Ratio of ROMPs to other professionals and the population in general.

\begin{tabular}{|c|c|c|c|c|c|c|c|}
\hline & \multirow{2}{*}{$\begin{array}{l}\text { Oncologists/ } \\
\text { ROMP ratio }\end{array}$} & \multirow{2}{*}{$\begin{array}{c}\text { Patients/ } \\
\text { ROMP } \\
\text { ratio }\end{array}$} & \multicolumn{2}{|c|}{ MV Machine/ROMP } & \multirow{2}{*}{$\begin{array}{c}\text { Populatio } \\
\mathbf{n} \\
\text { (millions) }\end{array}$} & \multicolumn{2}{|c|}{ MV Machine/Mn Pop } \\
\hline & & & 2008 & 2011 & & 2008 & 2011 \\
\hline Australia & 1.3 & 300 & 0.54 & 0.47 & 22.7 & 5.83 & 5.73 \\
\hline Bangladesh & 6.1 & 8696 & 1.56 & 0.956 & 159 & 0.09 & 0.14 \\
\hline Brunei & 1.0 & & & & 0.4 & & \\
\hline Hong Kong China & 2.0 & 250 & 0.79 & 0.74 & 7.1 & 4.71 & 4.51 \\
\hline India & 2.0 & 300 & 0.70 & 0.54 & 1210 & 0.34 & 0.36 \\
\hline Indonesia & 1.0 & 350 & 0.76 & 0.79 & 238 & 0.13 & 0.14 \\
\hline Japan & 3.4 & 778 & & 1.47 & 128 & & 6.46 \\
\hline Republic of Korea & 2.5 & 730 & 1.55 & 1.47 & 49 & 2.07 & 2.43 \\
\hline Malaysia & 0.6 & 350 & & 0.41 & 27.5 & & 1.20 \\
\hline Mongolia & 2.0 & 1000 & 0.67 & 0.50 & 2.8 & 0.67 & 0.71 \\
\hline Myanmar & 5.0 & 1500 & & 1.50 & 48 & & \\
\hline Nepal & 0.5 & 450 & 0.70 & 0.70 & 29 & 0.24 & 0.24 \\
\hline New Zealand & 1.0 & 250 & & 0.45 & 4.4 & & 5.68 \\
\hline Pakistan & 3.0 & 1200 & & 0.83 & 177 & & 0.22 \\
\hline Papua New Guinea & & & & & 6.7 & & \\
\hline Philippines & 1.3 & 400 & 1.00 & 0.88 & 94 & 0.32 & 0.38 \\
\hline PR China & 4.0 & 400 & 1.18 & 1.13 & 1339 & 1.04 & 1.27 \\
\hline Singapore & 2.0 & 400 & 1.38 & 1.06 & 5.1 & 3.91 & 3.53 \\
\hline Sri Lanka & 2.0 & 1500 & 1.38 & 1.33 & 21 & 0.52 & 0.57 \\
\hline $\begin{array}{l}\text { Republic of China } \\
\text { (Taiwan) }\end{array}$ & 1.5 & 300 & 1.14 & 0.93 & 23 & 5 & 5.74 \\
\hline Thailand & 1.2 & 330 & 0.78 & 0.84 & 67 & 0.9 & 1.01 \\
\hline Vietnam & 1.4 & & 0.92 & 0.62 & 87 & 0.27 & 0.36 \\
\hline Total (mean) & 2.0 & 614.6 & (mean 0.96) & (mean 0.88) & & (mean 1.9) & (mean 2.1) \\
\hline
\end{tabular}

we also inquired about the requirement for ROMPs to work overtime.

4. Professional organisations

5. Resources available

6. Research and teaching

7. Job satisfaction in the areas of professional recognition, remuneration, and workload.

In addition to this questionnaire, participants were invited to provide as many free form comments as necessary. The questionnaire was sent out by email in March 2011 and the original time frame for answering the questions was four weeks; however, answers were accepted beyond the four-week period. They reflect the status of March to August 2011. On some occasions, additional details were elicited and provided in communication with participants.

\section{RESULTS}

Answers were received from all 22 countries/territories, representing more than 3500 medical physicists. This constitutes a response rate of $100 \%$ compared to $80 \%$ in 2008 [2].

Tables 1 to 5 show the results. The numbering and structure of the tables is identical to that used in the original publication [2] to facilitate easy comparisons. Two tables (2 'staff numbers and equipment' and 3 'workload') were split into two tables each to make access to the data easier. Table 2 also contains a direct contrasting of figures from 2008 and 2011.

As in 2008, about half of the respondents provided additional information in free form. This information was included in the tables wherever possible and additional comments shown are in table 5 .

\section{DISCUSSION}

As the profession of medical physicists is maturing and international organisations such as the IAEA and the IOMP are aiming to standardise education and practice, it is of interest to explore how medical physicists fare in the Asia Pacific region. The fast and comprehensive reply of respondents in all countries/territories approached illustrates that this interest is shared by ROMPs. The higher response rate $(100 \%$ in 2011 compared with $80 \%$ in 2008) may reflect increasing professional awareness but could also be a result of allowing more time for completion of the questionnaires. 
Table 3a Workload of ROMPs.

\begin{tabular}{|c|c|c|c|c|c|c|c|c|}
\hline & \multicolumn{3}{|c|}{ Clinical } & \multirow[b]{2}{*}{$\begin{array}{c}\text { Official } \\
\text { working } \\
\text { hours }\end{array}$} & \multicolumn{4}{|c|}{ Other } \\
\hline & $\begin{array}{c}\text { QA, } \\
\text { calibration, } \\
\text { commissioning }\end{array}$ & $\begin{array}{l}\text { Engineering/ } \\
\text { maintenance }\end{array}$ & $\begin{array}{c}\text { Radiotherapy } \\
\text { Treatment } \\
\text { Planning }\end{array}$ & & Administration & $\begin{array}{l}\text { Radiation } \\
\text { Protection }\end{array}$ & IT & $\begin{array}{l}\text { Research } \\
\text { and } \\
\text { teaching }\end{array}$ \\
\hline Australia & 10 & 2 & 4 & 38 & 2 & 2 & 4 & 4 \\
\hline Bangladesh & 3 & 2 & 6 & $\begin{array}{l}\text { work hours } \\
\text { differ } \\
\text { public and } \\
\text { private }\end{array}$ & 3 & 1 & 1 & 2 \\
\hline Brunei & no data yet & & & & & & 10 & 10 \\
\hline $\begin{array}{l}\text { Hong Kong } \\
\text { China }\end{array}$ & 10 & 5 & 12 & 44 & 5 & 4 & 4 & 4 \\
\hline India & 10 & 2 & 16 & & 6 & 2 & 1 & 5 \\
\hline Indonesia & & 2 & 15 & 40 & & 2 & & 8 \\
\hline Japan & 13 & 3 & 13 & 40 & 8 & 2 & 10 & 20 \\
\hline $\begin{array}{l}\text { Republic of } \\
\text { Korea }\end{array}$ & 12 & 2 & 10 & & 10 & 1 & & 20 \\
\hline Malaysia & 10 & & 15 & & 2 & 2 & 1 & 2 \\
\hline Mongolia & 1 & 1 & 10 & 35 & 1 & 1 & 1 & 1 \\
\hline Myanmar & 1 & 3 & 5 & & $\begin{array}{l}\text { "all of duty } \\
\text { time" }\end{array}$ & 2 & $\begin{array}{l}\text { a few } \\
\text { hours }\end{array}$ & 0 \\
\hline Nepal & 7 & & 26 & 42 & 1 & 2 & 0.5 & 1 \\
\hline New Zealand & 15 & 3 & 7 & 38 & 5 & 2 & 5 & 3 \\
\hline Pakistan & 9 & 2 & 20 & 40 to 45 & 6 & 2 & 2 & 4 \\
\hline $\begin{array}{l}\text { Papua New } \\
\text { Guinea }\end{array}$ & no data & & & & & & & \\
\hline Philippines & 3 & 1 & 20 & 40 & 12 & 2 & 2.5 & 2 \\
\hline PR China & 10 & 6 & 30 & 40 to 50 & 2 & 1 & 6 & 1 \\
\hline Singapore & 15 & 3 & 15 & 42 & 4 & 1 & 2 & 1 \\
\hline Sri Lanka & 2 & 1 & 30 & & 2 & 2 & 1 & 3 \\
\hline $\begin{array}{c}\text { Republic of } \\
\text { China (Taiwan) }\end{array}$ & 5 & 1 & 28 & 40 & 3 & 1 & 2 & 3 \\
\hline Thailand & 10 & 0 & 20 & & 2 & 1 & 2 & 5 \\
\hline Vietnam & 8.5 & 1 & 27.5 & $\begin{array}{c}42(\text { six } \\
\text { days/week) }\end{array}$ & 2.5 & 1.5 & 4.5 & 1.5 \\
\hline Average & 8.1 & 2.2 & 16.5 & & 4.25 & 1.7 & 3.3 & 4.0 \\
\hline
\end{tabular}

\section{Education, training and professional certification}

As in 2008, all respondents agreed on the need for a combination of academic education and clinical training. This is in line with developments all over the world. In most countries, the need for postgraduate education specialising in medical physics was also acknowledged. It will be a challenge to ensure that access to these courses is available everywhere. The internet provides a unique opportunity here and web-based resources can at least provide some of the required content [6]. While the need for a $\mathrm{PhD}$ [7] is not apparent in the answers, Table 1 shows that several countries give candidates with a $\mathrm{PhD}$ advanced standing and reduce requirements for other training. This practice needs to be considered case by case as academic education cannot necessarily replace clinical experience.

There is no doubt that medical physicists working in radiation oncology require a high level of training and specialisation. Taking into account a higher degree and clinical training that typically takes at least two years, entry into the profession typically requires at least seven years of specialist education after high school completion. As such, ROMPs are amongst the most highly trained professionals without a medical degree in hospitals.

It is therefore not surprising to find a trend towards a requirement for professional certification of medical physicists $[8,9]$. Patients and other medical professionals find it difficult to judge the competence of ROMPs. As such, they need to rely on peer review and assessment to ensure that skills and experience of medical physicists are appropriate for the complexity of the tasks to be undertaken. This is particularly important as ROMPs are often engaged in work with significant safety implications for patients, staff, and the public. Radiation protection is one of these areas and ROMPs in all surveyed countries spend at least one hour per week on average on this activity, as can be seen in Table $3 a$. 
Table 3b Involvement of ROMPs in research and teaching and the requirement of doing overtime.

\begin{tabular}{|c|c|c|c|c|c|c|}
\hline & \multicolumn{2}{|c|}{ Research } & \multicolumn{2}{|c|}{ Teaching } & \multicolumn{2}{|c|}{ Overtime } \\
\hline & Participation & $\begin{array}{l}\text { Clinical } \\
\text { trials }\end{array}$ & $\begin{array}{c}\text { To } \\
\text { physicists }\end{array}$ & To others & $\begin{array}{c}\text { \% of staff } \\
\text { working } \\
\text { regular } \\
\text { working OT }\end{array}$ & $\begin{array}{c}\text { Overtime } \\
\text { allowance? }\end{array}$ \\
\hline Australia & $\mathrm{y}$ & some & $\mathrm{y}$ & $\begin{array}{c}\text { oncologists, } \\
\text { RTs }\end{array}$ & $>50$ & $\begin{array}{c}\text { often time in } \\
\text { lieu }\end{array}$ \\
\hline Bangladesh & $\mathrm{y}$ & $\mathrm{n}$ & $\mathrm{y}$ & $\begin{array}{c}\text { oncologists (in } \\
\text { process) }\end{array}$ & 50 & no \\
\hline Brunei & $\mathrm{y}$ & $\mathrm{n}$ & & diagn radiol & 100 & no \\
\hline $\begin{array}{l}\text { Hong Kong } \\
\text { China }\end{array}$ & $\mathrm{y}$ & $\mathrm{y}$ & $\mathrm{y}$ & $\begin{array}{l}\text { wide variety of } \\
\text { teaching tasks }\end{array}$ & 70 & no \\
\hline India & $\begin{array}{l}\mathrm{y} \text { in teaching } \\
\text { hospitals }\end{array}$ & $\begin{array}{l}\mathrm{y} \text { in some } \\
\text { centres }\end{array}$ & $\mathrm{y}$ & $\mathrm{y}$ & $>50$ & $\begin{array}{c}\text { some clinics } \\
\text { yes }\end{array}$ \\
\hline \multicolumn{7}{|l|}{ Indonesia } \\
\hline Japan & & & & & & \\
\hline $\begin{array}{l}\text { Republic of } \\
\text { Korea }\end{array}$ & & & & & most & $\begin{array}{l}\text { only junior } \\
\text { staff }\end{array}$ \\
\hline Malaysia & not all & very few & $\mathrm{y}$ & $\mathrm{y}$ & 50 & no \\
\hline Mongolia & not yet & $\begin{array}{l}\text { in } \\
\text { planning }\end{array}$ & $\begin{array}{c}\text { in } \\
\text { discussion }\end{array}$ & & most & not sufficient \\
\hline Myanmar & & & & & most & no \\
\hline Nepal & sometimes & sometimes & & $\begin{array}{c}\text { y RadOncs and } \\
\text { BSc Technol }\end{array}$ & no & no \\
\hline New Zealand & $\begin{array}{c}\text { small } \\
\text { percentage }\end{array}$ & $\mathrm{y}$ & & $\begin{array}{c}\text { RadOncs and } \\
\text { RTs }\end{array}$ & 5 & yes \\
\hline Pakistan & $\mathrm{y}$ & $\begin{array}{l}\text { not in } \\
\text { general }\end{array}$ & $\mathrm{y}$ & $\mathrm{y}$ & 35 & $\begin{array}{l}2 / 3 \text { have } \\
\text { allowance }\end{array}$ \\
\hline $\begin{array}{l}\text { Papua New } \\
\text { Guinea }\end{array}$ & not applicable & & & & & \\
\hline Philippines & limited & $\begin{array}{c}\text { in } \\
\text { planning }\end{array}$ & $y$ & $\mathrm{y}$ & 99 & $\begin{array}{l}\text { some yes, } \\
\text { many no }\end{array}$ \\
\hline PR China & $\begin{array}{l}\text { Participation } \\
\text { in research }\end{array}$ & few & & $\begin{array}{l}\text { in uni centres - } \\
\text { med students }\end{array}$ & 60 & no \\
\hline Singapore & some & some & & $\begin{array}{c}\text { y RTs and } \\
\text { medical } \\
\text { officers }\end{array}$ & 30 & no \\
\hline Sri Lanka & few & no & & $\begin{array}{l}\text { MD oncology, } \\
\text { radiol, } \\
\text { radiography }\end{array}$ & most & $\begin{array}{l}\text { no, but } \\
\text { requested }\end{array}$ \\
\hline $\begin{array}{l}\text { Republic of } \\
\text { China (Taiwan) }\end{array}$ & $\mathrm{y}$ & $\mathrm{y}$ & $\mathrm{y}$ & $\mathrm{y}$ & most & no \\
\hline Thailand & $\mathrm{y}$ & $\mathrm{y}$ & & $\mathrm{y}$ & 100 & yes \\
\hline Vietnam & few & not often & $\mathrm{y}$ & $\mathrm{y}$ & 15 & $\begin{array}{l}\text { yes but not } \\
\text { quite } \\
\text { satisfactorily }\end{array}$ \\
\hline
\end{tabular}

While the survey did not probe if certification was actually required in a country to practice medical physics, it can be assumed that this is likely to become the norm in the future.

In the context of certification and credentialing, professional organisations play an essential role. As such it is good to see in Table 4 that most countries/territories have a professional association that represents medical physicists and, at least in principle, could oversee a certification scheme. International organisations such as
IOMP and AFOMP can facilitate communication between these organisations, possibly help with mutual recognition, and further assist in defining standards to assess medical physics practice.

Finally, it is important to note that CPD is an integral part of most certification procedures $[9,10]$. In a fast-changing technological environment such as radiation oncology medical physics, this is particularly essential. As such, education of ROMPs does not end with graduation and there could be opportunities for 
Table 4 Professional organizations and access to resources - for explanation of acronyms for the professional organizations, please refer to appendix 1 .

\begin{tabular}{|c|c|c|c|c|c|c|c|}
\hline & \multicolumn{3}{|c|}{ Professional organisations } & \multicolumn{3}{|c|}{ Access to* } & \multirow[b]{2}{*}{$\begin{array}{c}\text { Internet } \\
\text { access } \\
(\%)\end{array}$} \\
\hline & Medical Physics & $\begin{array}{c}\text { Number } \\
\text { of } \\
\text { members }\end{array}$ & $\begin{array}{c}\text { Other } \\
\text { relevant } \\
\text { organisations }\end{array}$ & $\begin{array}{l}\text { Dosimetry } \\
\text { equipment }\end{array}$ & literature & $\begin{array}{c}\text { Discussion } \\
\text { with } \\
\text { colleagues }\end{array}$ & \\
\hline Australia & ACPSEM & 450 & $\begin{array}{c}\text { ARPS, } \\
\text { AAPM, IPEM }\end{array}$ & $\mathrm{e}$ & $\mathrm{e}$ & $\mathrm{g}$ & 100 \\
\hline Bangladesh & BMPS & 86 & some & $\mathrm{a}$ & g & g & 90 \\
\hline Brunei & no & & & $\mathrm{g}$ & $\mathrm{a}$ & $\mathrm{a}$ & 100 \\
\hline $\begin{array}{l}\text { Hong Kong } \\
\text { China }\end{array}$ & HKAMP & 82 & $40 \% \mathrm{o} / \mathrm{s}$ & $\mathrm{e}$ & $\mathrm{e}$ & $\mathrm{g}$ & 100 \\
\hline India & $\begin{array}{l}\text { AMPI and } \\
\text { brachysociety }\end{array}$ & 1900 & yes & $\mathrm{e}$ & g & $\mathrm{e}$ & 99 \\
\hline Indonesia & HFMBI/IKAFMI & 48 & & g & a & a & 100 \\
\hline Japan & JSMP & 1720 & JSRT & $\mathrm{e}$ & $\mathrm{e}$ & $\mathrm{e}$ & $>80$ \\
\hline $\begin{array}{l}\text { Republic of } \\
\text { Korea }\end{array}$ & KSMP & 275 & yes & g & $\begin{array}{l}\text { a, private } \\
\text { hospitals } \\
\text { may have } \\
\text { problems }\end{array}$ & g & 100 \\
\hline Malaysia & $\begin{array}{l}\text { MIP/MP } \\
\text { subgroup, } \\
\text { MAMP }\end{array}$ & 35 & yes & g & g & $\mathrm{g}$ & 99 \\
\hline Mongolia & starting & & no & $\mathrm{a}$ & g & $\mathrm{a}$ & 100 \\
\hline Myanmar & $\begin{array}{c}\text { National } \\
\text { committee } \\
\text { through RAS } \\
6053\end{array}$ & & no & a & $\mathrm{n}$ & $\mathrm{a}$ & 50 \\
\hline Nepal & NAMP & 10 & y (AAPM) & $\mathrm{g}$ & $\mathrm{n}$ & $\mathrm{a}$ & 60 \\
\hline New Zealand & ACPSEM & 77 & $\mathrm{y}$ & $\mathrm{a}$ & $\mathrm{g}$ & $\mathrm{g}$ & 100 \\
\hline Pakistan & POMP & & $\begin{array}{l}\text { PSCO, PSC, } \\
\text { RSP, PSNM }\end{array}$ & $\mathrm{a}$ & a & g & 90 \\
\hline $\begin{array}{l}\text { Papua New } \\
\text { Guinea }\end{array}$ & & & & $\mathrm{a}$ & $\mathrm{a}$ & $\mathrm{n}$ & 100 \\
\hline Philippines & POMP & 88 & PARP & $\begin{array}{c}\text { most a, } \\
\text { few } n\end{array}$ & $\mathrm{n}$ & $\mathrm{g}$ & 100 \\
\hline PR China & CSMP & 1500 & $\begin{array}{c}\text { most are } \\
\text { members of } \\
\text { CSRO; } 100 \\
\text { IPEM }\end{array}$ & $\begin{array}{l}\text { n except } \\
\text { for top } \\
\text { centres }\end{array}$ & $\begin{array}{l}\text { a except } \\
\text { for top } \\
\text { centres }\end{array}$ & $\begin{array}{c}\text { only in } 25 \% \\
\text { of centres }\end{array}$ & 90 \\
\hline Singapore & $\begin{array}{c}\text { SMP (Society of } \\
\text { MP) }\end{array}$ & 16 & $\mathrm{y}$ & $\mathrm{e}$ & g & $\mathrm{g}$ & 100 \\
\hline Sri Lanka & SLMPA & 8 & $\mathrm{n}$ & $\mathrm{a}$ & $\mathrm{a}$ & $\mathrm{a}$ & 75 \\
\hline $\begin{array}{l}\text { Republic of } \\
\text { China (Taiwan) }\end{array}$ & CSMPT & 250 & y (CSTRO) & $\mathrm{e}$ & $\mathrm{e}$ & $\mathrm{e}$ & 100 \\
\hline Thailand & TMPS & 120 & $\begin{array}{c}\text { Radiol Soc } \\
\text { Thailand, } \\
\text { AAPM }\end{array}$ & $\mathrm{a}$ & g & $\mathrm{g}$ & 100 \\
\hline Vietnam & VAMP & 450 & $\begin{array}{l}\text { Viet Soc } \\
\text { Cancer }\end{array}$ & $\mathrm{n}$ & $\mathrm{a}$ & $\mathrm{g}$ & 30 \\
\hline Total & & 7107 & & & & & \\
\hline
\end{tabular}

* Categories: excellent: e, good: g, acceptable: a, not adequate: $\mathrm{n}$

using educational materials both during the training of students as well as for CPD of experienced ROMPs. This could overcome some of the problems associated with economies of scale in developing educational materials for a small but highly specialised profession.

\section{Resources and staffing}

As can be seen in Table 2a, the number of medical physicists in the region has increased by $29 \%$ since 2008 . This increase applies to virtually all countries with a notable exception of a few smaller workforces. However, the number of megavoltage treatment units in the region has also increased significantly since 2008 and therefore the ratio of machines per ROMP has only decreased slightly as can be seen in Table 2b. In 2009, AFOMP published its recommendations for staffing levels for medical physicists [11]. Given the variation in practice, it is difficult to apply these figures rigorously; however, given the complexity of work, it appears that the present number of ROMPs is still on the low side of these recommendations. 
Table 5 Job satisfaction of ROMPs and general comments (1 worst, 5 best).

\begin{tabular}{|c|c|c|c|c|}
\hline \multicolumn{5}{|c|}{ Work conditions/job satisfaction } \\
\hline & $\begin{array}{l}\text { Professional } \\
\text { recognition }\end{array}$ & Remuneration & $\begin{array}{l}\text { Workload } \\
(1=\text { too much, } \\
5=\text { easy })\end{array}$ & Comments \\
\hline Australia & 4 & 4 & 2 & $\begin{array}{l}\text { variation in states; significant improvement } \\
\text { over last years }\end{array}$ \\
\hline Bangladesh & 3 & 3 & 1 & $\begin{array}{l}\text { more training required; AFOMP, IAEA play } \\
\text { important role }\end{array}$ \\
\hline Brunei & 3 & 3 & 2 & $\begin{array}{l}\text { not sufficient understanding of med phys in } \\
\text { administration; radiation does not have high } \\
\text { priority' }\end{array}$ \\
\hline $\begin{array}{l}\text { Hong Kong } \\
\text { China }\end{array}$ & 4 & 3 & 2 & \\
\hline India & 3 & 3 & 1 & $\begin{array}{l}\text { remuneration varies between govt and } \\
\text { private }\end{array}$ \\
\hline \multicolumn{5}{|l|}{ Indonesia } \\
\hline Japan & 1 & 1 & 3 & $\begin{array}{l}\text { most med phys tasks are performed by } \\
\text { 'radiological technologists'; they are well } \\
\text { trained to do the job but not called medical } \\
\text { physicists; eighty percent of medical } \\
\text { physicists now also have license of } \\
\text { radiological technologist. }\end{array}$ \\
\hline $\begin{array}{l}\text { Republic of } \\
\text { Korea }\end{array}$ & 2 & 2 & 2 & $\begin{array}{l}\text { KSMP is persuing legislation for medical } \\
\text { physics }\end{array}$ \\
\hline Malaysia & 2 & 3 & 3 & $\begin{array}{l}\text { professional recognition needs to be } \\
\text { improved; accreditation program needed } \\
\text { developing country cannot afford to }\end{array}$ \\
\hline Mongolia & 5 & 3 & 2 & $\begin{array}{l}\text { participate in } \mathrm{o} / \mathrm{s} \text { training; } \mathrm{CPE} \text { and training } \\
\text { could be regional? }\end{array}$ \\
\hline Myanmar & 3 & 2 & 1 & \\
\hline Nepal & 2 & 3 & 3 & $\begin{array}{l}\text { medical physics is new and as such } \\
\text { recognition not good; not an IAEA member }\end{array}$ \\
\hline New Zealand & 2 & 3 & 3 & \\
\hline Pakistan & 3 & 4 & 3 & $\begin{array}{l}\text { no med phys courses at uni - lack of research } \\
\text { culture; most work routine - promotion } \\
\text { should come also from outside }\end{array}$ \\
\hline $\begin{array}{l}\text { Papua New } \\
\text { Guinea }\end{array}$ & & & & $\begin{array}{l}\text { no permanent physicist - remote support } \\
\text { from Australia }\end{array}$ \\
\hline Philippines & 4 & 3 & 2 & $\begin{array}{l}\text { ROMP salary not standardised, POMP has } \\
\text { no negotiation power; quite a number of } \\
\text { med physicists work in regulatory agencies } \\
\text { status has improved with 3D CRT and }\end{array}$ \\
\hline PR China & 2 & 2 & 2 & $\begin{array}{l}\text { IMRT; no professional title as yet - hinders } \\
\text { promotion }\end{array}$ \\
\hline Singapore & 3 & 3 & 3 & \\
\hline Sri Lanka & 2 & 1 & 1 & $\begin{array}{l}\text { recently } 17 \text { physicists with BSc were } \\
\text { recruited; training is needed }\end{array}$ \\
\hline $\begin{array}{l}\text { Republic of } \\
\text { China (Taiwan) }\end{array}$ & 4 & 3 & 2 & \\
\hline Thailand & 4 & 3 & 2 & \\
\hline Vietnam & 2 & 2 & 3 & $\begin{array}{l}\text { IAEA assistance needed; QA tools - daily - } \\
\text { required }\end{array}$ \\
\hline
\end{tabular}

Table 2 also shows that many countries have implemented intensity modulated radiation therapy (IMRT) $[12,13]$ and image guided radiation therapy (IGRT) $[14,15]$. As a matter of fact, these technologies have become so widely used that some respondents did not even mention them in the survey. The availability of complex treatment units such as Cyberknife surgery and helical tomotherapy has also increased substantially from 2008 to 2011. While the availability of equipment does not necessarily indicate its extensive use, the commissioning of equipment - which is independent of workload - is one of the core activities of medical 
physicists in radiation oncology [16]. Additional tasks such as planning and individual patient quality assurance (QA) will increase with clinical utilisation, increasing the workload as the added complexity presents additional risks and thus requirements for QA $[17,18]$.

Table 4 shows that access to the Internet is now available virtually everywhere. This provides significant opportunities for the future as the Internet has become an essential tool for information exchange and access to resources for medical physicists. On the other hand, the availability of specialised dosimetric equipment has not improved dramatically since 2008 . Given the increasing complexity of the equipment in most countries, this is of considerable concern.

\section{Typical tasks and workloads for ROMPs}

As can be seen in Table 3a, most of the workload for ROMPs is clinical with treatment planning being the predominant role in most countries. As such, it is fair to say that ROMPs are members of the clinical team directly involved in patient care (albeit not always with patient contact). However, the survey shows that ROMPs also spent a significant amount of time on a large variety of duties including provision of information technology services and radiation protection. The results of this part of the survey illustrate a shortcoming of the simple questionnaire as the large variety of work practices had to be compressed into few categories. This will result in some variation in the interpretation of the answers.

However, there is no doubt that there is significant breadth in the work of medical physicists. This is also illustrated in their involvement in research and teaching, as shown in Table 3b. As can be seen, many physicists are involved in education of other professionals in the hospital environment. This confirms the importance of medical physics concepts but also exposes a shortcoming as most medical physics training does not include teaching and communication skills. Similarly, future training requirements would also need to consider research and professional ethics [19].

Table $3 \mathrm{~b}$ also summarises the results of the questions regarding overtime. Given the nature of medical physics work, it is common that out-of-hours work is required. This is often in the form of overtime that extends work hours beyond normal working hours. As Table $3 \mathrm{~b}$ shows, ROMPs in most countries are required to perform overtime work. It is concerning that this is expected but often not adequately compensated. The routine requirement for overtime work also confirms the fact that staffing levels are typically less than adequate for all the tasks required of ROMPs.

\section{Status and job satisfaction}

The perceived high workload is also reflected in Table 5. Most respondents felt that the workload for medical physicists is too high. From the simple questions in the present survey, it is difficult to compare the results directly with 2008. However, it appears that workloads have increased while the professional recognition and remuneration has stayed more or less constant. In any case, it appears that the disparities between countries have not substantially reduced between 2008 and 2011 .

\section{Limitations of the survey}

Any survey conducted with individuals representing whole countries and territories has limitations as many countries have complex healthcare systems with a large diversity of tasks and practices. A particular concern is the availability of public and private facilities in most countries that often serve different patient groups and may have considerably different equipment and work practices. The fact that only one person completed the survey in each country will introduce some bias to the results; however, the personal contact amongst the authors ensures that the response rate can be as high as it has been.

Another limitation is the fact that work practices of medical physicists in radiation oncology are different in different countries, as can be seen in Table 3. Therefore some tasks may actually be taken up by other professionals and possibly technicians. While this is not accounted for in the survey, it can be assumed that the physicists will also take on other responsibilities that are not part of their core duties. In assessing staff numbers per machine or population as in Table 2, it was assumed that there is a balance between delegated and newly acquired tasks.

\section{CONCLUSION}

As organisations such as the ILO start to recognise medical physics as a profession, it is evident that, despite some encouraging signs, there is still a lot of work required towards establishing an adequately trained and resourced medical physics workforce in the Asia Pacific region. The significant increase in the number of ROMPs in the region between 2008 and 2011 is matched by similar increases in radiation oncology equipment and complexity of treatment approaches. As further increases in the use of radiation for cancer treatment can be expected, it will be important to continue also the growth of the medical physics profession.

\section{ACKNOWLEDGEMENT}

We would like to thank W. van der Putten and A. Meghzifene from the International Atomic Energy Agency for their helpful comments.

\section{APPENDIX 1: ACRONYMS FOR PROFESSIONAL ASSOCIATIONS}

AAPM: American Association of Physicists in Medicine

ACPSEM: Australasian College of Physical Scientists and Engineers in Medicine

AFOMP: Asia-Oceania Federation of Organizations for Medical Physics 
AMPI: Association of Medical Physicists of India ARPS: Australasian Radiation Protection Society

CSMP: Chinese Society of Medical Physics

CSMPT: Chinese Society of Medical Physics, Taipei

CSRO: Chinese Society of Radiation Oncology

CSTRO: Chinese Society for Therapeutic Radiology and Oncology

HFMBI: Indonesian Medical Physics and

Biophysics Association

HKAMP: Hong Kong Association of Medical Physics

IKAFMI: Indonesian Medical Physics Association

IOMP: International Organization for Medical Physics

IPEM: Institute of Physics and Engineering in

Medicine

JRS: Japan Radiological Society

JSMP: Japan Society of Medical Physics

JSRT: Japanese Society of Radiological Technology

KSMP: Korean Society of Medical Physics

MAMP: Malaysian Association of Medical Physics

MIP/MP: Malaysian Institute of Physics, Medical

Physics Subgroup

NAMP: Nepalese Association of Medical Physicists

PARP: Philippine Association for Radiation

Protection

POMP: Pakistan Organization of Medical Physicists

POMP: Philippine Organization of Medical

Physicists

PSC: Pakistan Society of Cancer

PSCO: Pakistan Society of Clinical Oncology

PSNM: Pakistan Society of Nuclear Medicine

RSP: Radiological Society of Pakistan

SLMPA: Sri Lanka Medical Physics Association

SMP: Society of Medical Physicists (Singapore)

TMPS: Thai Medical Physicists Society

VAMP: Vietnam Association for Medical Physics

\section{REFERENCES}

1. International Labour Organization. ISCO-08 Structure and preliminary correspondence with ISCO-88. [Online]. [cited 2011 September]. Available from: http:/www.ilo.org/public/english/bureau/stat/isco/isco08/index.htm

2. Kron T, Cheung K, Dai J, Ravindran P, Soejoko D, Inamura K, Song J, Bold L, Srivastava R, Rodriguez L, Wong T, Kumara A, Lee C, Krisanachinda A, Nguyen X and Ng Kh. Medical physics aspects of cancer care in the Asia Pacific region. Biomed Imaging Interv J 2008;4(3):e33.

3. $\mathrm{Ng} \mathrm{KH}$, Cheung KY, Hu YM, Inamura K, Kim HJ, Krisanachinda A, Leung J, Pradhan AS, Round H, van Doomo T, Wong TJ and Yi BY. The role, responsibilities and status of the clinical medical physicist in AFOMP. Australas Phys Eng Sci Med 2009; 32(4):175-179

4. Perkins, A and Kron, T. Continuing professional development needs of Australian radiation oncology medical physicists - an analysis of applications for CPD funding. Australas Phys Eng Sci Med 2007; 30(3):226-232.

5. Stefanoyiannis AP, Christofides S, Psichis K, Geoghegan DS, Gerogiannis I, Round WH, Geronikola-Trapali X, Armeniakos I, Kaplanis PA, Prentakis A and Chatziioannou SN. The Education and training of clinical medical physicists in 25 European, 2 North American and 2 Australasian countries: Similarities and differences. Phys Med 2012; 28(3):183-190.
6. Meyer J, Hartmann B and Kalet I. A 'learning-by-doing' treatment planning tutorial for medical physicists. Australas Phys Eng Sci Med 2009; 32(2):112-117.

7. Mills MD, Elson HR and Orton CG. Point/counterpoint. The terminal M.S. degree is no longer appropriate for students interested in a career in clinical medical physics in the United States. Med Phys 2011; 38(4):1737-1739.

8. Round, WH. Certification and licensing of clinical medical physicists in AFOMP countries. Australas Phys Eng Sci Med 2011; 34(3):309-315.

9. Kron $\mathrm{T}$ and $\mathrm{Ng} \mathrm{KH}$. An overview of credentialing and certification. In: Pawlicki T, Dunscombe P, Mundt A, Scalliet P, eds. Quality and Safety in Radiotherapy. Boca Raton, Florida: Taylor \& Francis, 2011; 179-184.

10. Madewell JE, Hattery RR, Thomas SR, Kun LE, Becker GJ, Merritt $\mathrm{C}$ and Davis LW. Maintenance of certification. J Am Coll Radiol 2005; 2(1):22-32.

11. Round WH, Tay YK, Ng KH, Cheung KY, Fukuda S, Han Y, Huang YX, Kim HJ, Krisanachinda A and Liu HL; Asia-Oceania Federation of Organizations for Medical Physics. AFOMP POLICY STATEMENT No. 2: recommended clinical radiation oncology medical physicist staffing levels in AFOMP countries. Australas Phys Eng Sci Med 2010; 33(1):7-10.

12. Hartford AC, Palisca MG, Eichler TJ, Beyer DC, Devineni VR, Ibbott GS, Kavanagh B, Kent JS, Rosenthal SA, Schultz CJ, Tripuraneni $\mathrm{P}$ and Gaspar LE; American Society for Therapeutic Radiology and Oncology; American College of Radiology. American Society for Therapeutic Radiology and Oncology (ASTRO) and American College of Radiology (ACR) Practice Guidelines for Intensity-Modulated Radiation Therapy (IMRT). Int J Radiat Oncol Biol Phys 2009; 73(1):9-14.

13. Webb S. Intensity-modulated radiation therapy (IMRT): a clinical reality for cancer treatment, "any fool can understand this". The 2004 Silvanus Thompson Memorial Lecture. Br J Radiol 2005; 78(Spec No 2):S64-S72.

14. Korreman S, Rasch C, McNair H, Verellen D, Oelfke U, Maingon P, Mijnheer B and Khoo V. The European Society of Therapeutic Radiology and Oncology-European Institute of Radiotherapy (ESTRO-EIR) report on 3D CT-based in-room image guidance systems: A practical and technical review and guide. Radiother Oncol 2010; 94(2):129-144.

15. van Herk M. Different styles of image-guided radiotherapy. Semin Radiat Oncol 2007; 17(4):258-267.

16. Balter S and Balter JM. Anniversary paper: A sampling of novel technologies and the role of medical physicists in radiation oncology. Med Phys 2008; 35(12):5641-5652.

17. Ibbott GS, Molineu A and Followill DS. Independent evaluations of IMRT through the use of an anthropomorphic phantom. Technol Cancer Res Treat 2006; 5(5):481-487.

18. Palta JR, Liu C and Li JG. Quality assurance of intensitymodulated radiation therapy. Int J Radiat Oncol Biol Phys 2008; 71(Suppl 1):S108-S112.

19. Serago CF, Adnani N, Bank MI, BenComo JA, Duan J, Fairobent L, Freedman DJ, Halvorsen PH, Hendee WR, Herman MG, Morse RK, Mower HW, Pfeiffer DE, Root WJ, Sherouse GW, Vossler MK, Wallace RE and Walters B; American Association of Physicists in Medicine. Code of Ethics for the American Association of Physicists in Medicine: report of Task Group 109 Med Phys 2009; 36(1):213-223. 


\section{University Library}

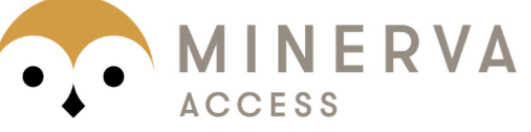

A gateway to Melbourne's research publications

Minerva Access is the Institutional Repository of The University of Melbourne

\section{Author/s:}

Kron, T;Azhari, H;Voon, E;Cheung, K;Ravindran, P;Soejoko, D;Inamura, K;Han, Y;Ung, N;Bold, L;Win, U;Srivastava, R;Meyer, J;Farrukh, S;Rodriguez, L;Kuo, M;Lee, J;Kumara, A;Lee, C;Krisanachinda, A;Nguyen, X;Ng, K

Title:

Medical physics aspects of cancer care in the Asia Pacific region: 2011 survey results.

Date:

2012-04

\section{Citation:}

Kron, T., Azhari, H., Voon, E., Cheung, K., Ravindran, P., Soejoko, D., Inamura, K., Han, Y., Ung, N., Bold, L., Win, U., Srivastava, R., Meyer, J., Farrukh, S., Rodriguez, L., Kuo, M., Lee, J., Kumara, A., Lee, C. ,... Ng, K. (2012). Medical physics aspects of cancer care in the Asia Pacific region: 2011 survey results.. Biomed Imaging Interv J, 8 (2), pp.e10-. https:// doi.org/10.2349/biij.8.2.e10.

Persistent Link:

http://hdl.handle.net/11343/262566

License:

CC BY 